日植病報 $38: 414-425(1972)$

Ann. Phytopath. Soc. Japan 38: 414-425 (1972)

\title{
Biological and Ecological Studies on the Sclerotium of Pellicularia sasaleii (Shirai) S. Ito
}

\section{Floating on the water surface of sclerotium*}

\author{
Teruyoshi Hashiba**, Tomio Yamaguchi*** \\ and Shizuo MogI** \\ 羽柴輝良**・山口富夫***・茂木静夫** : イ不紋枯病菌菌核の生理・ \\ 生態に関する研究 I. 菌核の水中浮沈について*
}

\begin{abstract}
The sclerotia of Pellicularia sasakii produced on rice plants at an early stage of development sink under water after dropping from the rice plants, but float on water surface with maturing within one month after formation. Experiments were carried out for elucidating the floating structure of natural and cultured sclerotia (PDA).

The structure of floating sclerotia has two distinct layers, inner and outer layers. The inner layer consists of mass of living cells and the outer layer of empty cells. The width of the outer layer is over $200 \mu \mathrm{m}$. The outer layer of sinking sclerotia is narrow with less than $150 \mu \mathrm{m}$ and surrounded by hyphal cells. All sclerotia of this size sink under water but they float slightly with aging. The floated sclerotia has a wider outer layer and do not have a layer of hyphal cells. On the other hand, the outer layer of cultured sclerotia is narrower, and can not float on the water surface. On the part of the outer layer, the hyphal cells can be clearly seen.

From these results, it is concluded that the floating on the water surface of the sclerotium is associated closely with the structure of the outer layer.
\end{abstract}

(Received April 6, 1972)

\section{Introduction}

Rice sheath blight on rice plants in Japan has increased rapidly in recent years since it was discovered by Yano in 1915, and has become an important problem next to rice blast disease. It is assumed that the occurrence of this disease in Japan has recently increased in association with the increase of the early transplanting cultivation and the use of early maturing varieties. Numbers of studies have been presented.

The dissemination of the disease has been studied by Endo ${ }^{2)}$, Ikata and Hitomi ${ }^{8}$, Kozaka ${ }^{10)}$ and Yokogi15). Overwintered sclerotia in the soil float on the water surface as a result of pudding and leveling operations. Then, they begin to adhere and fix to the leaf sheath of the rice plant and infect them by germination. Thereby, it is clear that sclerotia has a very important role in the dissemination of this disease.

The properties of sclerotia on surviving in the soil and others have been studied in detail by

* A part of this paper was presented at the annual meeting of phytopathological society of Japan in April, 1971.

** Hokuriku National Agricultural Experiment Station, Joetsu, Niigata, Japan. 北陸農業試験場

*** National Institute of Agricultural Sciences, Kita-ku, Tokyo, Japan. 農業技術研究所 
many investigators ${ }^{2,3,9,10,15)}$. The structure of the sclerotia has also been discribed ${ }^{2,5,6,14)}$. However, any definite relationship has not been reputed between their structure and their floating ability on the water surface.

The sclerotia floating on the water surface play very important roles in the outbreak of this disease and recently, this has been studied ${ }^{11,19)}$.

The sclerotia at an early stage of development sink under water then float with ripping ${ }^{11)}$. Experiments were carried out for elucidating their floating ability on the water surface in relation to the structure of sclerotia. The experimental results are presented this paper.

\section{Materials and methods}

The sclerotia of Pellicularia sasakii (Shirai) S. Ito. used in this observation were collected from the infected rice plants in paddy fields in 1970 or 1971, according to experiments. As a control, cultured sclerotia are used, which were produced on a potato-dextrose-agar (PDA) at 25C for one month.

In these experiments, the terms are defined below. "Natural sclerotia" are the ones formed on the rice plant. "Cultured sclerotia" are the ones formed on a PDA. "Sinking sclerotia" are natural sclerotia which sink under water surface at an early stage of sclerotial development. "Floating sclerotia" are natural sclerotia which float on the water surface after maturity.

Details of the methods will be given each experiment.

\section{Results}

\section{Floating of natural and cultured sclerotia}

In this experiment, the relationships between the time after formation of the sclerotia and the floating ability of the sclerotia on the water surface were observed.

The sclerotia were collected indiscriminately from the affected rice plants in paddy fields from

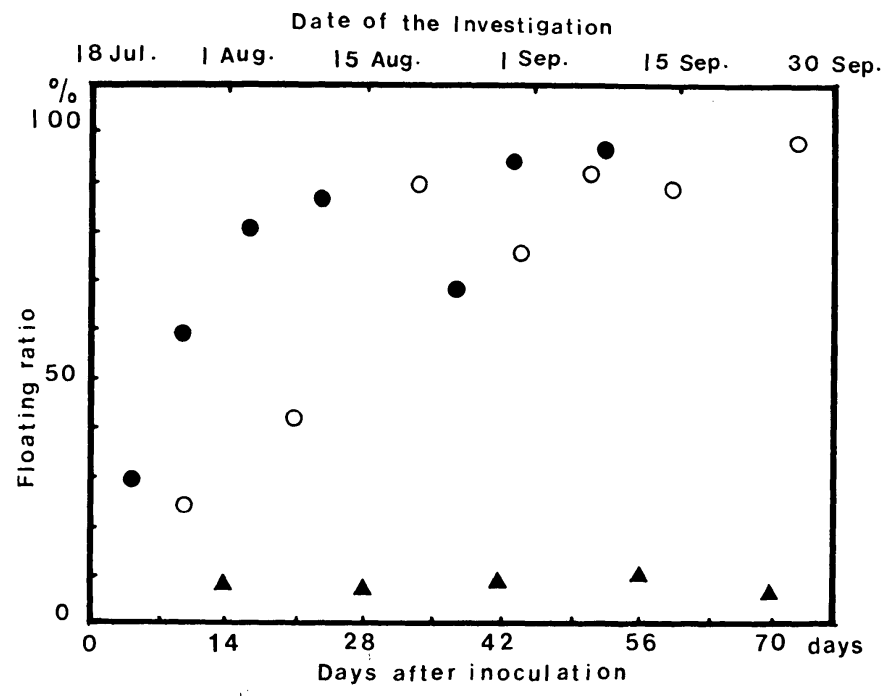

Fig. 1. Floating of the natural and the cultured sclerotia.

O Natural sclerotia, 1970.

- Natural sclerotia, 1971.

- Cultured sclerotia. 
late July to late September in 1970 and 1971. As a control, cultured sclerotia were used. The collected sclerotia were immersed in the water for 60 minutes stirring to mix. The number of floating sclerotia were counted. A floating ratio of the cultured sclerotia was investigated at 14,28 , 42,56 and 70 days after culturing on media, respectively. Two hundred to 300 sclerotia were used in every experiment.

The results are indicated in Fig. 1. Only about $30 \%$ of the sclerotia collected in the later part of July floated on the water surface. Their floating ratio tended to increase when they were collected later the paddy fields. All sclerotia collected toward the end of September floated on the water surface. The time which is necessary to float on the water surface after formation appears to be about 2 months. However, it seems to be shorter than that because they were formed continuously on rice plants in paddy fields till the later part of September and consequently all developmental stages of sclerotia were observed at the same time.

On the other hand, when 70 days old cultured sclerotia were immersed in the water for 60 minutes only about $10 \%$ of them floated on the water surface, then the rest sank under water with prolongation of immersion time. It was indicated that the cultured sclerotia did not float on the water surface regardless of age.

\section{The time until of floating}

The time required to float on the water surface after formation on rice plants was investigated.

Three days old sinking sclerotia after formation on rice plants were preserved in a vessel at $25 \mathrm{C}$ and under $40,60,80$ and $100 \%$ relative humidity, respectively. The relation between preservation time and floating on the water surface of the sclerotia was examined. Each relative humidity was adjusted with sulfuric acid. The experimental methods were the same as in the experiments described in previous section.

The results are indicated in Fig. 2. When sinking sclerotia were preserved in a vessel for 15 days under 80 and $100 \%$ relative humidity, about $90 \%$ floated on the water surface. While they

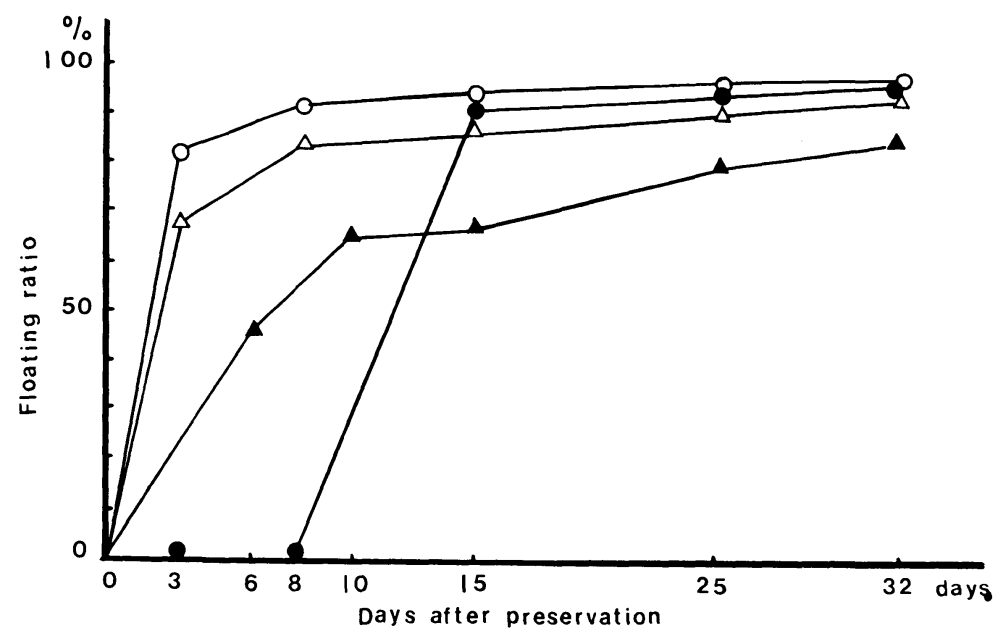

Fig. 2. The time of preservation until to floating on the water surface (Preservation in a vessel under $15 \mathrm{C}$ ).

- $100 \%$ relative humidity.

○ $80 \%$ relative humidity.

- $60 \%$ relative humidity.

$\triangle \quad 40 \%$ relative humidity. 
were preserved at a lower humidity, the rate of the floating increased slightly with preservation time. When the sclerotia were; preserved for 32 days under 40 and $60 \%$ relative humidity, the greater part of the sclerotia floated on the water surface. From these results, it was indicated that sinking sclerotia changes into the floating sclerotia within one month from initial formation under these experimental conditions. Thus, it is considered that sclerotia formed on rice plants in paddy fields change into floating sclerotia within one month after formation.

\section{Relationships between amount of water content and floating of sclerotia}

The experiments were carried out to clarify the relation between the floating of sclerotia and their water content.

The natural sclerotia and the cultured sclerotia which immersed into the water for 15 hours were preserved in a vessel at 40,80 and $100 \%$ relative humidity, respectively. The water content was investigated at $0,1,2,3$ and 5 days after the preservation at each relative humidity, respectively. The water content was measured by an indirect weight method. The dry weight of samples was determind by drying at 105-110C for 24 hours.

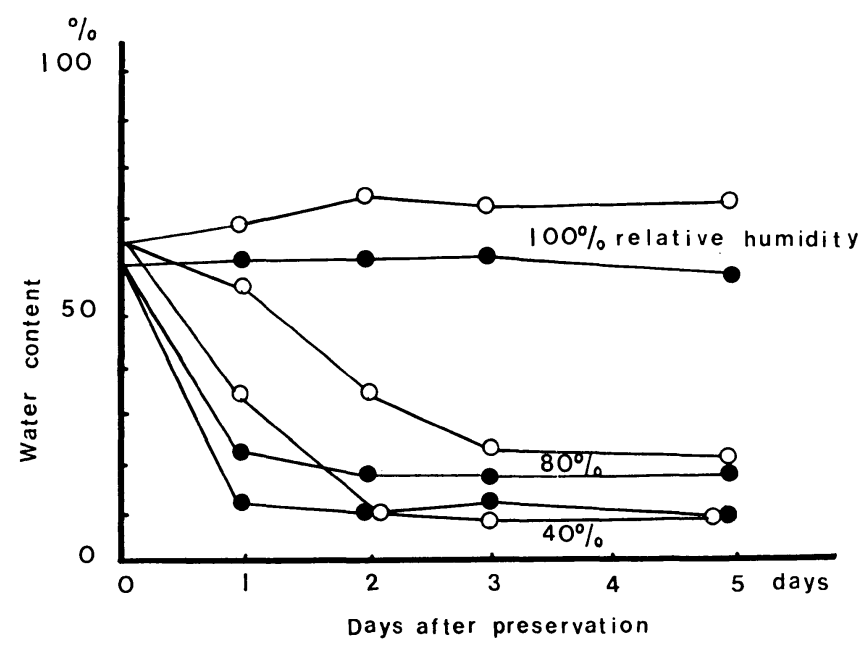

Fig. 3. Amount of water content of the natural and the cultured sclerotia.

- Natural sclerotia.

O Cultured sclerotia.

The results indicated in Fig. 3. The natural sclerotia floated on the water surface for 15 hours contained about $60 \%$ water and the cultured sclerotia sunk under water contained about $70 \%$ water. The floating and the cultured sclerotia which were preserved in a vessel at $40 \%$ relative humidity reduced the water content to about $10 \%$ after 1-2 days, then this value is held constant. The sclerotia which were preserved in a vessel at $80 \%$ humidity reduced the water content to about $20 \%$ after 2-3 days, then this value is held constant.

From the above results, even if the water content of the cultured sclerotia decreses more than that of floating sclerotia, the cultured sclerotia will sink under water, so it is concluded that the floating of the sclerotia does not appear to be caused by the water content.

\section{Specific gravity of sclerotia}

In these experiments, the specific gravities of the natural sclerotia and the cultured sclerotia were 
investigated.

On the natural sclerotia which usually float on the water, the specific gravity of the sclerotia were measured by using the air comparison pycnometer, model 930 (Beckman-Toshiba, LTD.). The 6 mohths old natural sclerotia and the one month old cultured sclerotia were used in this experiment. After preservation in a vessel for 1,2 and weeks under $40 \%$ relative humidity, respectively, all sclerotia were measured.

Results are shown in Table 1. The floating sclerotia showed a specific gravity of 1.2-1.3, while the cultured sclerotia showed a value of 1.6-1.7. The specific gravities of the floating sclerotia were

Table 1. Specific gravities of the natural and the cultured sclerotia

\begin{tabular}{lccc}
\hline \hline \multirow{2}{*}{ Sclerotial condition } & \multicolumn{3}{c}{ Preservation time (weeks) } \\
\cline { 2 - 4 } & 1 & 2 & 3 \\
\hline Cultured sclerotia of one month old & 1.72 & 1.65 & 1.69 \\
Natural sclerotia of six months old & 1.23 & 1.27 & 1.24 \\
\hline
\end{tabular}
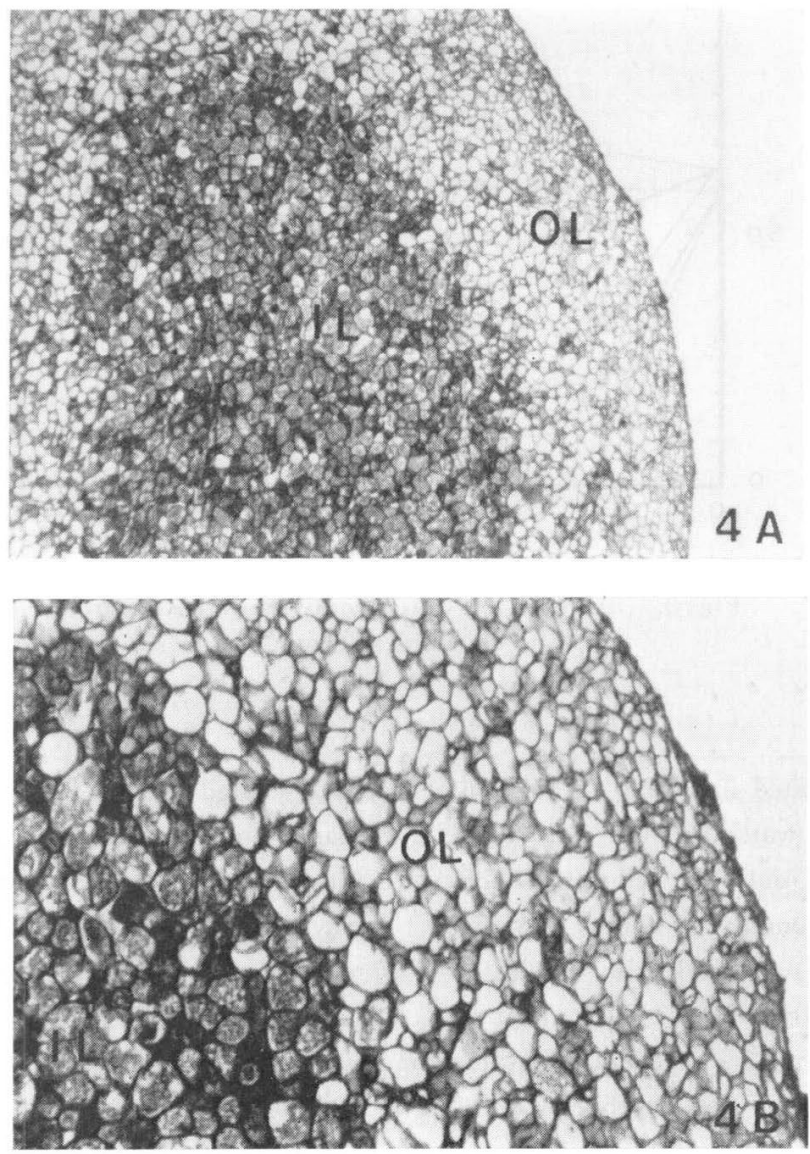

Fig. $4 \mathrm{~A}$, B. The structure of the floating sclerotia.

IL: Inner layer (a mass of living cells).

OL: Outer layer (empty cells). 
bigger than that of water. Yamaguchi et al.19) suggested that the specific gravities were estimated by the behavior of sclerotia in liquds of various specific gravities, and natural sclerotia showed a specific gravity of $0.8-0.9$. As mentioned above, the different values of specific gravity were obtained by different methods, and the phenomenon may be based on the existence of hydrophoric materials on the surface of the sclerotia or its empty cell structures.

\section{Structure of the natural and the cultured sclerotia}

The structures of the sinking, floating, and cultured sclerotia were observed by using an optical microscope.

Each sclerotia was fixed in Bouin's solution, and sectioned by the usual paraffin method. The sections were double-stained with erythrosin and Delafield's-hematoxylin.

Results are shown in Fig. 4-6. The structure of the floating sclerotia has two distinct layers consisting of an inner layer and an outer layer. The inner layer is formed with a mass of living cells. These living cell are filled with densely stained cytoplasm by an erythrosin. The outside of living cells has layer consisting of empty cells. Towards the margin, the dimensions of the cells of the outer layer are slightly less, but there are no well-defined protective tissue. The inner and the outer layer were consistently observed in the sections.
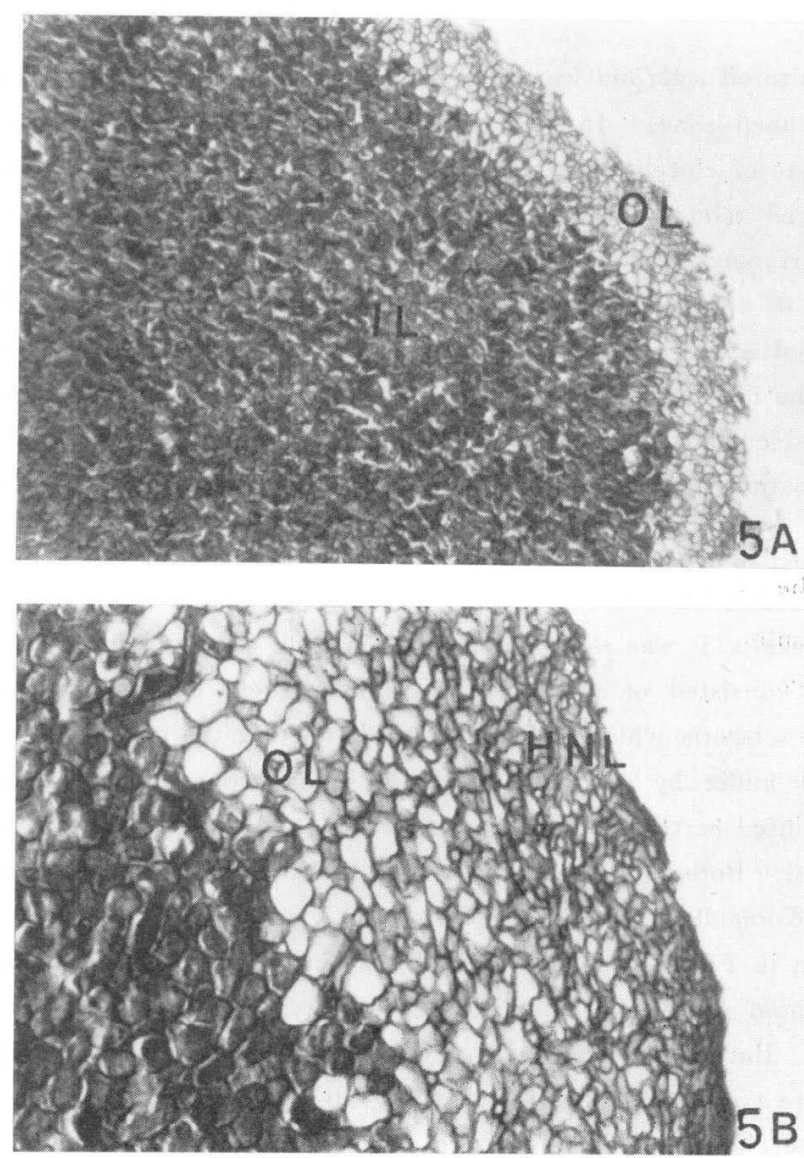

Fig. $5 \mathrm{~A}$, B. The structure of the sinking sclerotia. HNL: The layer of the cells of a hypha like. 


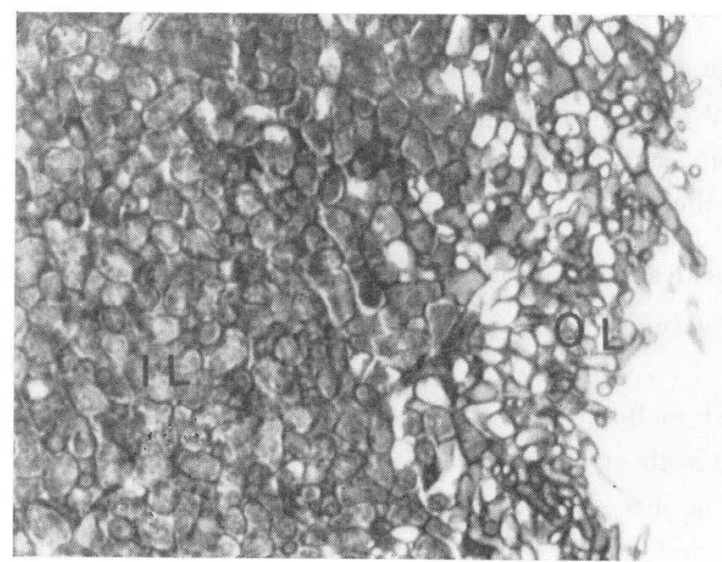

Fig. 6. The structure of the cultured sclerotia.

The structures of the sinking sclerotia are very similar to those of the floating sclerotia, both in an inner layer and an outer layer. But it was recognized that the outer layer is surrounding by the hypha like cells. The layer of the hypha like cells was not easily distinguished from the empty cells of the outer layer.

In contrast, the cultured sclerotia were recognized to have the inner and the outer layers, but there were no well-defined zones. In most of them, the hyphal cells can be clearly seen. The natural sclerotia consists of closely packed cells, and there are a few intercellular spaces in these tissues. In the cultured sclerolia, these tissues are characterized by the intercellular spaces, and appear to be loosely arranged cells.

For the structure of the sclerotia, it was found that there was a large difference between the natural and the cultured sclerotia. Moreover, for the natural sclerotia, it was found that there was a difference between the floating and the sinking sclerotia. We can presume that the floating on the water surface of the sclerotia is based on the difference of those structures. In other words, it is presumed that the floating ability on the water surface of the sclerotia depends on the layer of empty cells.

\section{Empty cells of the outer layer}

From the above results, it was assumed that the outside of the living cells of the sclerotia had an outer layer which consisted of empty cells. So subsequent experiments were done to observe the outer layer of the sclerotia which is treated for elucidating the empty cell.

The sclerotia sink under by the addition of $1 \%$ medicated soap or boiling treatment. These treated sclerotia were used as the experimental materials, and the floating sclerotia of non-treatment were used as a control. Both of the sclerotia were sectioned by using the thermo-electric froezing microtome, type 101 (Komatsu Solidate Co, LTD.).

Results are shown in Fig. 7-10. The cells of the outer layer of the naturally floating and the sinking sclerotia appeared to be empty, and these cells were observed as black in color by bubbles under the microscope. But some of the cells of the outer layer did not show black in color, because the empty cell cut into two pieces were filled with water. From this reason, an empty cell of the outer layer is observed clearly as black in color when the sections were cut into more than $20 \mu$ in thickness.

On the other hand, the part of the outer layer of the treated selerotia by the addition of 

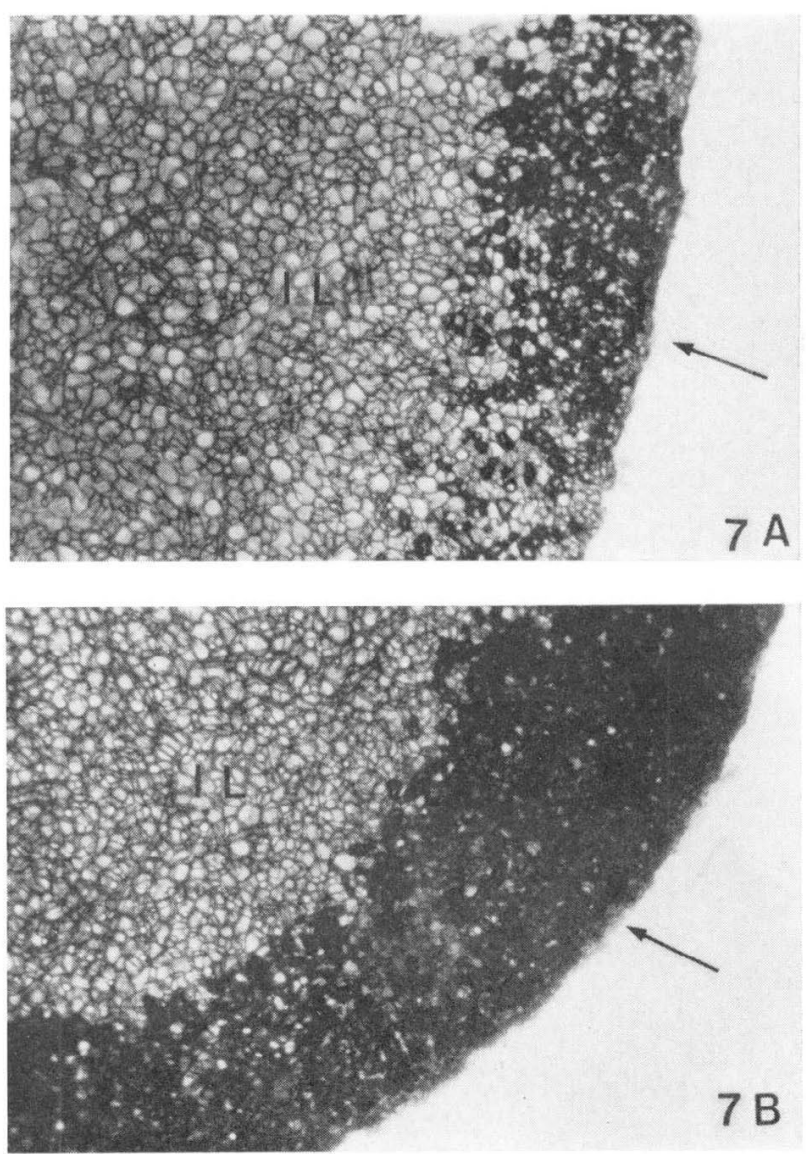

Fig. $7 \mathrm{~A}, \mathrm{~B}$. The cells of the outer layer of the floating sclerotia. These cells were observed as black in color by bubbles under the microscope (arrow).

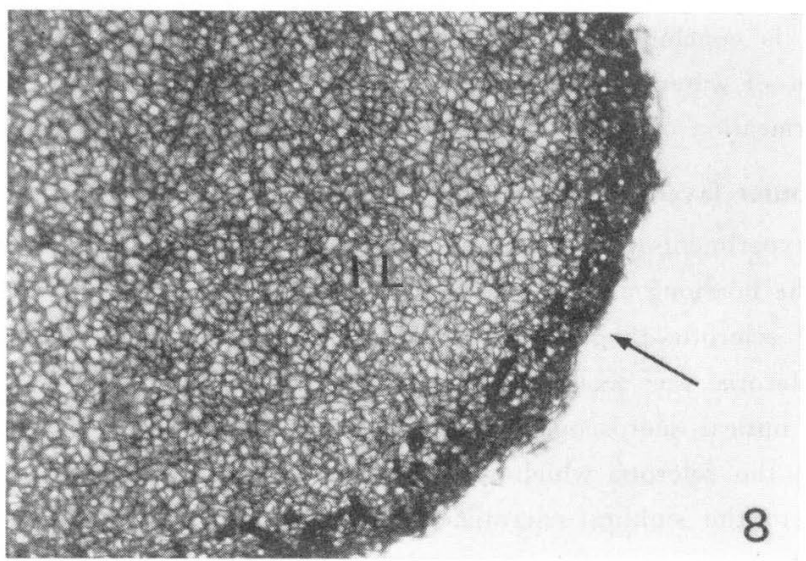

Fig. 8. The cells of the outer layer of the sinking sclerotia. 


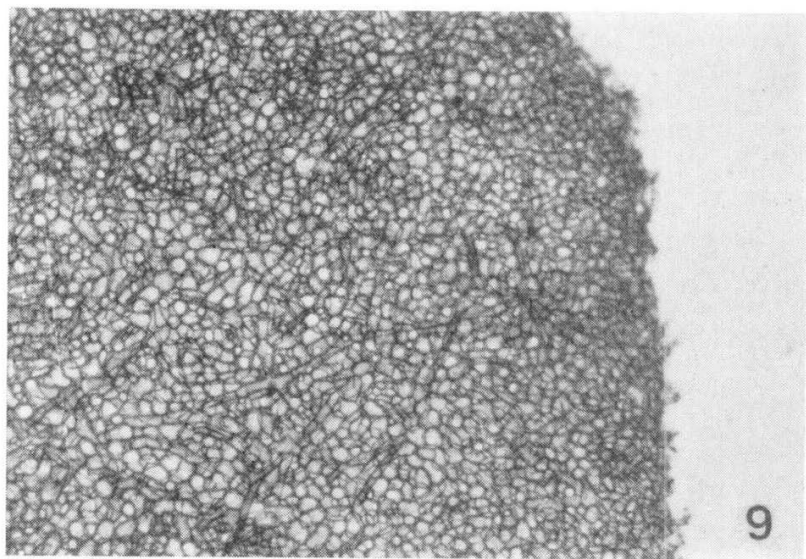

Fig. 9. The sclerotia which are sunk under water by the addition of medicated soap or the boiling treatment.

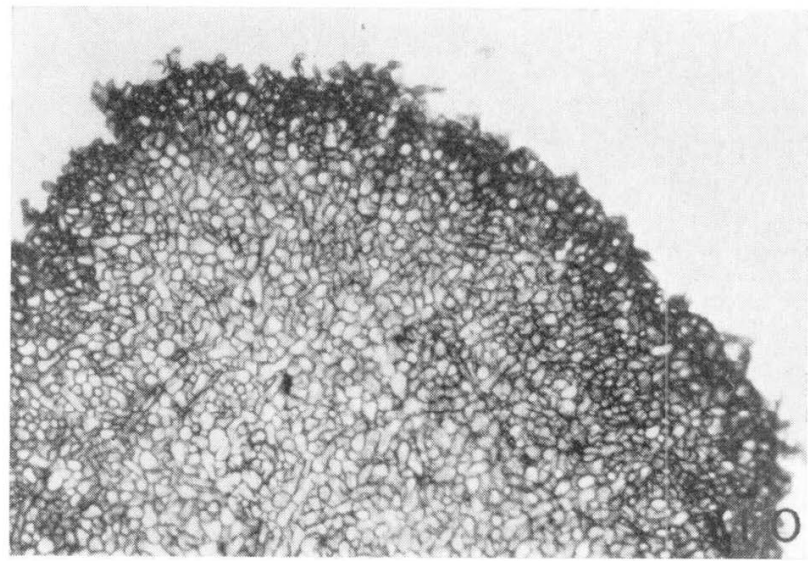

Fig. 10. The cells of the outer layer of the cultured sclerotia.

medicated soap or by the boiling treatment does not appear to be empty and all cells were full of water. Therefore, it is concluded that the addition of medicated soap or the boiling treatment causes the permeation of water into the empty cells of the sclerotia. We could not really clarify the mechanism of permeation of water into the empty cells by these treatment.

\section{Width of the outer layer of sclerotia}

From the above experiments on the structure of the sclerotia, the relation between the width of the outer layer and the floationg ability was examined.

Various stages of sclerotia ranging from sinking under water to floating on the water surface were used. Each sclerotia was fixed and stained by the method described previously, and was observed by using an optical microscope.

The structures of the sclerotia which sank under water after preservation in a vessel at each humidity are similar to the sinking sclerotia. The structure of both sclerotia has three layers consisting of an inner layer, an outer layer and a hyphal nature layer. On the other hand, the structures of the sclerotia which floated on the water surface after preservation in a vessel do not have a layer of a hypha like and are similar to those of the floating sclerotia. 
Table 2. Width of the outer layer of sclerotia

\begin{tabular}{lc}
\hline \multicolumn{1}{c}{ Sclerotial condition } & $\begin{array}{c}\text { An average width } \\
\text { of } \begin{array}{c}\text { the outer layer } \\
(\mu)\end{array}\end{array}$ \\
\hline 1.5 years old sclerotia (Floating sclerotia) & 262 \\
Six months old sclerotia (Floating sclerotia) & 252 \\
15 days old sclerotia (Sinking sclerotia) & 142 \\
The sclerotia which sank under water after the preservation & 153 \\
The sclerotia which floated on the water surface after the preservation & 197 \\
\hline
\end{tabular}

The width of the outer layer, part of the empty cells described above, was observed. The results are indicated in Table 2. The width of the outer layer of 1.5 years old sclerotia was $262 \mu$. Six months old sclerotia, floating sclerotia, measured $252 \mu$ in average width. On the other hand, the sinking sclerotia was $142 \mu$ wide and also the sclerotia which sank under water after the preservation in a vessel was $153 \mu$ wide. The width of the outer layer of these sclerotia become narrower than that of the floating sclerotia. Namely, it was indicated that in the sinking sclerotia, the number of empty cells was poor. The width of the outer layer of the sclerotia which floated on the water after the preservation in a vessel increased to $197 \mu$. When the surface of the natural sclerotia becomes brown with the development, the cell of the outer layer begins to empty (unpublished) and also the width of the outer layer increases, so it is considered that the ratio of floating on the water surface of the sclerotia increases slightly.

\section{Discussion}

It is well known that the sclerotia of Pellicularia sasakii float on the water surface. Kozaka ${ }^{10)}$ reported that the sclerotia which float on the water surface never sink under water. Recently, Yamaguchi et al.19) have carried out experiments to clarify why the natural sclerotia usually float on the water surface while the cultured sclerotia sink under water. In their experiment, the specific gravities of sclerotia were estimated by using the liquids of various specific gravities, and natural sclerotia showed a specific gravity of $0.8-0.9$ while the cultured sclerotia showed a value of 1.1-1.3. Also they showed that when $1 \%$ of certain surface active agents was added into the water, the sclerotia sink gradually resulting from the permeation of water into them.

Our data indicated that the specific gravity of floating sclerotia which were measured by using the air comparison pycnometer showed 1.2-1.3, while the cultured sclerotia showed the value of 1.6-1.7. It was recognized that the cultured sclerotia were heavier in comparison with the natural sclerotia, and the specific gravities of the floating sclerotia were bigger than that of the water. It is assumed that the different values of specific gravity were obtained by different methods, and the phenomenon may be based on the existence of hydrophoric materials on the surface of the sclerotia or its empty cell structures.

Nakata and Kawamura ${ }^{14}$ indicated that in regard to the structure of the sclerotia, there is no differentiation of an inner and an outer layer and they consisted of closely packed hyphal cells. But Endo $^{2)}$ and Hemmi and Endo ${ }^{5,6)}$ reported that the sclerotia of this fungus were divided into four stages of development, and that the sections of oldest of Pellicularia sasakii are differentiated into outer and inner portions by stainning with eosin or acid fuchsin. But their reports did not appear to be definite about the nature of the empty cells which from the outer layer. Recently, Naiki and $\mathrm{Ui}^{13)}$ reported that in Rhizoctonia solani, the sclerotia have well-defined layers and have the outer layer 
consisting of empty cells in which cytoplasm has disappeared.

The experiments were carried out for elucidating the relation between the floating on the water surface and the outer layer of the sclerotia. The data indicated that the structure of the floating sclerotia has two distinct layers consisting of an inner layer and an outer layer. The inner layer of a sclerotia is formed with a mass of living cells. The outside of the living cells had the outer layer which appeared to be empty cells. In the freezing sections, these cells were observed as black in color by bubbles under the_microscope. Also, in electron microscopic sections of the sclerotia, cytoplasms were not observed in the cells. The cells consist of only cell wall (unpublished). From the above experiments, it is concluded that the outer layer of the sclerotia consists of empty cells.

The width of the outer layer of young sinking sclerotia is narrower than that of the floating sclerotia. In the outer layer there are a few empty cells, and a layer of the cells of a hyphal nature. All of the sclerotia of this stage sank under water, but float slightly with aging. The floated sclerotia increase the width of the outer layer of empty cell, but not a layer of a hyphal nature. On the other hand, the width of the outer layer of cultured sclerotia is narrower than the floating sclerotia; they do not float on the water surface. When the surfaces of the sclerotia begin to brown with development, namely after about 30 hours, the cells of the outer layer were recognized to begin to empty (unpublished). But the reason why there are a few empty cells in the cultured sclerotia is unknown.

In the cells of the sclerotia of rindless types, Nadakavukaren ${ }^{12}$ indicated that the layer heavywalled cells of Verticillium dahliae contained many large areas which appeared to be vacuoles. Brown and Whyllie') did not observe these vacuoles for the same fungus. Also, in some bulbils, an outer layer of empty cells encloses central cells with dense contents ${ }^{7)}$. In the sclerotia of Macrophomina phaseoli, Helicobasidium purpureum and Rhizoctonia tuliparum, there has been no report on this empty cells to date $\mathrm{e}^{16,17, \sim 18)}$.

Gordee and Porter $\left.{ }^{4}\right)$ reported that the cytoplasm of Verticillium dahliae sclerotia contains about $6 \%$ lipid when one month old but $22 \%$ lipid when nine months old. A lipid increase in the sclerotia of rice sheath blight with aging is unknown. From the sections which were stained with Sudan black $B$, the distribution of lipid droplets in the tissues of the floating sclerotia was recognized in the living cells, but very few in the empty cells. Therefore, it is concluded that lipid droplets are not important in floating on the water surface of this sclerotia.

Yamaguchi et al.19) recognized that the sclerotia sank gradually under water with the addition of certain surface active agents. Also our data recognized that the sclerotia are sunk under water by the addition of medicated soap or the boiling treatment. For this reason, it is concluded that the sinking of sclerotia is caused by permeation of water into the empty cells. Namely, it is indicated that in the natural sclerotia the water would not be permeated into the empty cells. The mechanism for the permeation of water into the empty cells by these treatments were not clarify still.

If the sclerotia have been sunk under water, it would not become a source of the outbreak of rice sheath blight of rice plants. So it is important to clarify the nature why the sinking sclerotia change into the floating sclerotia whithin a month after development. These problems must be further investigated.

\section{Acknowledgement}

The authors would like to acknowledge the continuing guidance and encouragement of Dr. I. Tamura, and also wish to express deepest appreciation to Dr. H. Suzuki and Mr. R. Yoshino of our laboratory for their valuable advice. 


\section{Literature cited}

1) Brown, M. F. and Wyllie, T. D. (1970). Phytopathology 60:538-542.

2) Endo, S. (1931). Forsch. a. d. Gebiet d. Pflanzenkr. (Kyoto). 1: 126-148.

3) Endo, S. (1931). Forsch. a. d. Gebiet d. Pflanzenkr. (Kyoto.) 1: 149-167.

4) Gordee, R. S. and Porter, C. L. (1961). Mycologia 53: 171-182.

5) Hemmi, T. and Endo, S. (1928). Memoris College Agri., Kyoto Imperial Univ. $7: 39-49$.

6) Hemmi, T. and Endo, S. (1929). Agriculture and Horticulture 4: 21-33.

7) Hotson, J. W. (1917). Botan. Gaz. 64: 265-284.

8) Ikata, S. and Hitomi, T. (1930). J. Plant Protection 17: 17-28.

9) Ikeno, S. (1934). Forsch. a. d. Gebiet d. Pflanzenkr. (Kyoto). 2: 238-256.

10) Kozaka, T. (1961). Chugoku Agri. Res. Assoc. 20: 1-133.

11) Kuramoto, T. and Yamaguchi, T. (1969). Proc. Assoc. Plant Prot. Hokuriku 17: 3-5.

12) Nadakavukaren, M. J. (1963). Canad. J. Microbiol. 9: 411-413.

13) Naiki, T. and Ui, T. (1969). Memoris Faculty Agri. Hokkaido Univ. 6: 430-438.

14) Nakata, K. and Kawamura, E. (1939). Mat. Improv. Agri., Min. Agri. Forest. Japan 139: 1-176.

15) Nozu, R. and Yokogi, K. (1936). Sp. Rep. Shimane Pref. Agri. Expt. Sta. 1-188.

16) Valder, P. G. (1958). Trans. Brit. Mycol. Soc. 41: 283-308.

17) Whetzel, H. H. and Arthur, J. M. (1925). Agri. Exp. Sta. Mem. 89: 1-7.

18) Wyllie, T. D. and Brown, M. F. (1970). Phytopathology $60: 524-528$.

19) Yamaguchi, T., Iwata, K. and Kuramoto, T. (1971). Bulletin Hokuriku Agri. Exp. Sta. 13: 15-34.

\section{和文摘要}

\section{1 六紋枯病菌菌核の生理・生態に関する研究}

\section{I. 菌核の水中浮沈について}

羽柴輝良・山口富夫・茂木静夫

イネ紋枯病菌（Pellicularia sasakii (Shirai) S. Ito.）菌核の水中における沈下および浮上の機作について， 菌核の形態，生理面から検討した。

稻体上に形成した菌核は蝎変，成熟後に落下し水中に沈下するが，菌核形成開始 1 力月以内には浮上する。 一方培養菌核 (PDA 培地) は水中でほとんど浮上することはない。

含水量ならびに比重を測定した結果，培養菌核は含水量が低下しても浮上しない。また空気比較式比重計に よる浮上菌核の比重は水より重い。この結果から菌核の内部形態が浮沈に関与していることが推定された。

浮上自然菌核の横断面組織形態は内層，外層の 2 層よりなり，内層は生細胞の mass，外層は空胞化細胞の mass である。空胞化細胞層の幅は $200 \mu$ 以上で菌核半径の約 $1 / 2$ を占めている。それにくらべてまだ浮上でき ない沈下自然菌核の外層の幅は狭く約 $150 \mu$ 以下であり，外層の外側に菌系層 (菌系状細胞の層)を残している。 時間とともに空胞化細胞層（すなわち外層）の增加，外側の菌系層の消減がおこり浮上できる菌核に变る経過を たどる。培着菌核の組織形態は外層, 内層の 2 層よりなるが，外層の幅が小さい上に多数の菌系状細胞が混在

し，空胞化細胞の形成がきわめて劣る。

以上のことから，菌核の水中浮沈に関与する要因は内部組織の形態変化，とくに外層を形成する空胞化細胞 の形成，菌系状細胞の消長に関係すると推定された。 